\title{
Physico-Chemical and Microbiological Analysis of Potable Water in Jericho and Molete Areas of Ibadan Metropolis
}

\author{
Olusola A. Ladokun, Sarah O. Oni \\ Lead City University, Ibadan, Nigeria \\ Email: solaJP@gmail.com
}

Received 11 March 2015; accepted 23 June 2015; published 29 June 2015

Copyright (C) 2015 by authors and Scientific Research Publishing Inc.

This work is licensed under the Creative Commons Attribution International License (CC BY). http://creativecommons.org/licenses/by/4.0/

(c) (;) Open Access

\begin{abstract}
This study was carried out to determine the quality of some water supplies in Jericho and Molete areas in Ibadan, Oyo State, Nigeria. A total of 6 water samples (Jericho and Molete) from well, borehole and public tap were randomly selected and analyzed in triplicate for some physico-chemical and microbial parameters. The $\mathrm{pH}$ ranged from $5.88 \pm 0.01$ to $6.88 \pm 0.06$ while total hardness ranged from $2.60 \pm 0.04 \mathrm{ppm}$ to $44.00 \pm 1.20 \mathrm{ppm}$. The temperature ranged from $15.00^{\circ} \mathrm{C} \pm 0.07^{\circ} \mathrm{C}$ to $18.00^{\circ} \mathrm{C} \pm 0.21^{\circ} \mathrm{C}$ while conductivity ranged from $230 \pm 1.15$ to $460 \pm 1.26 \mathrm{mho} / \mathrm{cm}$. Alkalinity, Dissolved Oxygen (DO) and Biochemical Oxygen Demand (BOD) ranged from $4.03 \pm 0.02 \mathrm{mg} / \mathrm{l}$ to $14.88 \pm 0.15 \mathrm{mg} / \mathrm{l}, 0.4 \pm 0.02 \mathrm{mg} / \mathrm{l}$ to $4.6 \pm 0.02 \mathrm{mg} / \mathrm{l}$ and $12.80 \pm 0.22 \mathrm{mg} / \mathrm{l}$ to $26.40 \pm 0.72 \mathrm{mg} / \mathrm{l}$ respectively. Microbial analysis revealed that all of these water samples were not free from pathogens and thereby not suitable for drinking.
\end{abstract}

\section{Keywords}

Water Alkalinity, BOD, Physico-Chemical Analysis

\section{Introduction}

Water is the most abundant substance found on the surface of the earth, covering roughly three quarters of the earth's surface and it plays a very vital role in existence as well as maintenance of life of organisms. Water related diseases continue to be one of the major health problems globally due to consumption of contaminated water. The high prevalence of diarrhea among children and infants can be traced to the consumption of unsafe water [1].

The most dangerous form of water pollution occurs when fecal contaminant like Escherichia coli enters the 
water supply. Also, the fecal-oral routes of transmission, in which pathogens are shed in human or animal faces. Containmants put into water supply which may perpetuate many diseases examples of such pathogen are Salmonella spp, Shigella spp, Vibrio choierae, Escherichia coli [2].

Typhoid fever remains a great socio-economic problem in developing countries, Nigeria inclusive. Perforation of intestines is associated with high mortality with wound infection occurring in 50\% - 75\% of survivals (Archimpong, 1976). Controlling wound sepsis or wound infection with various complications also affects mortality [3] [4] and unsafe drinking water has been the major source of this infection.

This paper is designed to determine the level of pollution or contamination of water in Molete and Jericho areas of Ibadan through the physico-chemical and microbial analysis of the three main water sources in each area.

The values of the physico-chemical and microbiological parameters were determined through laboratory water quality analysis to know if a particular source of water was suitable for drinking. The water quality of potable water in our towns and cities in Nigeria are often not known. Deviations from water quality standard of the World Health Organization (WHO) and European Economic Community (E.E.C) are contributory to health hazards and problems of most Nigerians. The National Agency for Food and Drug Administration and Control (NAFDAC) is established to regulate and maintain standards of food and drugs (including water) to promote the health of Nigerians. However, the physico-chemical properties of water in a given area need to be determined and established.

\section{Materials and Methods}

\subsection{Sample Collection}

A total of six (in triplicates) water samples (well, borehole and public tap) from two different areas in Ibadan were collected to determine the quality of drinking water supply in the metropolis as shown in Table 1.

Before water samples were collected, cotton wool soaked in $70 \%$ ethanol was used to sterilize the nozzle of the tap-outlet and the water was allowed to run for three minutes. The water samples were then collected into 2 $\mathrm{L}$ plastic container after thorough washing and rinsing with the respective water samples. The $2 \mathrm{~L}$ plastic container was filled to the brim to avoid air bubbles; the cap was then used to seal it firmly. The bottle was labeled and was kept in a cooler box containing ice, before being sent to the laboratory for analyses. Samples for microbial analysis were collected in a sterilized and phosphate free bottle.

\subsection{Method of Analysis}

The water quality parameters selected for the study were: $\mathrm{pH}$, temperature, dissolved oxygen, biochemical oxygen demand, conductivity, total hardness and alkalinity. $\mathrm{pH}$, temperature and $\mathrm{DO}$ parameters were measured insitu, with an ATI-Orion $\mathrm{pH}$ meter, thermometer probe and meter respectively. All the parameters were determined using Standard Methods of Analysis of Water and Wastewater [5].

\subsection{Microbiological Assessment}

The method for enumeration of total coli form bacteria as recommended by [6] was employed to determine the bacteriological quality of water samples.

\begin{tabular}{cc} 
Table 1. Sample location. & \\
\hline Sample & Location \\
\hline W1 (public tap water) & Molete, Ibadan. \\
W2 ( bore hole water) & Molete, Ibadan. \\
W3 ( well water) & Molete, Ibadan. \\
W4 (public tap water) & Jericho, Ibadan. \\
W5 (borehole water) & Jericho, Ibadan. \\
W6 (well water) &
\end{tabular}




\section{Result and Discussion}

The temperature for the two neighborhoods ranged from $15.00^{\circ} \mathrm{C} \pm 0.07^{\circ} \mathrm{C}$ to $18.00^{\circ} \mathrm{C} \pm 0.21^{\circ} \mathrm{C}$. The samples were taken in the morning and the temperature obtained for the samples were quite low as compared to the room temperature. The lowest temperature of $15.00^{\circ} \mathrm{C} \pm 0.07^{\circ} \mathrm{C}$ was recorded for borehole water at Molete while the highest value of $18.00^{\circ} \mathrm{C} \pm 0.21^{\circ} \mathrm{C}$ was recorded for borehole and well water at Jericho, Ibadan as shown in Figure 1 below.

High temperature is known to increase the toxicity of some substances such as ammonia, reduce the concentration of dissolved oxygen, increase water acidity and influence the activities of some microorganisms.

The DO values range from $0.4 \pm 0.02 \mathrm{mg} / \mathrm{l}$ to $4.6 \pm 0.02 \mathrm{mg} / \mathrm{l}$, Jericho borehole water recorded the highest value and Molete public tap water had the lowest value as shown in Figure 2 and in Table 2 below.

All the water samples in these neighborhoods had values below the $5 \mathrm{mg} / \mathrm{l} \mathrm{WHO}$ threshold [7] [8] as revealed in Table 2.

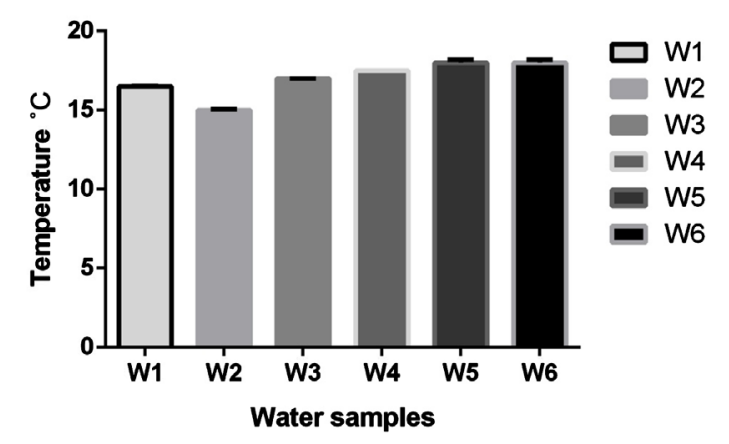

Figure 1. Temperature of the water samples.

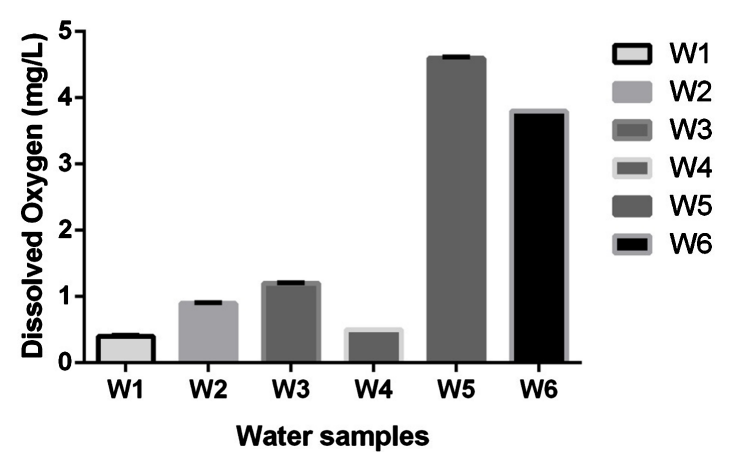

Figure 2. Dissolved oxygen of water samples.

Table 2. Physico-chemical and biological parameters of water samples from molete and jericho, ibadan.

\begin{tabular}{|c|c|c|c|c|c|c|c|c|}
\hline Sample & BOD mg/l & DO mg/l & $\mathrm{pH}$ & TEMP ${ }^{\circ} \mathrm{C}$ & $\begin{array}{c}\text { Hardness } \\
\mathrm{mg} / \mathrm{ml}\end{array}$ & $\begin{array}{l}\text { Alkalinity } \\
(\mathrm{mg} / \mathrm{l})\end{array}$ & $\begin{array}{l}\text { Conductivity } \\
\text { mho/cm }\end{array}$ & $\begin{array}{l}\text { Coliform count } \\
\text { (Cfu/ml) }\end{array}$ \\
\hline W1 & $24.30 \pm 0.08$ & $0.4 \pm 0.02$ & $6.60 \pm 0.00$ & $16.50 \pm 0.02$ & $44.00 \pm 1.20$ & $14.88 \pm 0.15$ & $460 \pm 1.26$ & $8.5 \times 10^{6} \pm 5.23$ \\
\hline W2 & $22.40 \pm 0.06$ & $0.9 \pm 0.01$ & $6.41 \pm 0.01$ & $15.00 \pm 0.07$ & $2.60 \pm 0.04$ & $9.25 \pm 0.03$ & $290 \pm 1.51$ & $8.0 \times 10^{6} \pm 11.14$ \\
\hline W3 & $18.20 \pm 0.35$ & $1.2 \pm 0.01$ & $6.87 \pm 0.02$ & $17.00 \pm 0.01$ & $42.00 \pm 0.13$ & $14.64 \pm 0.07$ & $320 \pm 2.34$ & $5.4 \times 10^{6} \pm 9.67$ \\
\hline W4 & $26.40 \pm 0.72$ & $0.5 \pm 0.00$ & $6.84 \pm 0.05$ & $17.50 \pm 0.00$ & $20.80 \pm 0.04$ & $4.03 \pm 0.02$ & $230 \pm 1.15$ & $9.8 \times 10^{6} \pm 17.81$ \\
\hline W5 & $12.80 \pm 0.22$ & $4.6 \pm 0.02$ & $6.88 \pm 0.06$ & $18.00 \pm 0.21$ & $11.20 \pm 0.11$ & $4.03 \pm 0.11$ & $290 \pm 2.77$ & $3.0 \times 10^{6} \pm 20.21$ \\
\hline W6 & $15.89 \pm 0.13$ & $3.8 \pm 0.00$ & $5.88 \pm 0.01$ & $18.00 \pm 0.20$ & $8.30 \pm 0.00$ & $4.26 \pm 0.02$ & $300 \pm 2.19$ & $4.2 \times 10^{6} \pm 22.10$ \\
\hline WHO & 3.0 & 5 & $6.5-8.5$ & Ambient & 150 & --------- & 1000 & 0 \\
\hline
\end{tabular}

Results were presented in mean \pm s.d for triplicate. BOD: Biochemical Oxygen Demand; DO: Dissolved Oxygen; WHO: World Health Organization. 
Adequate dissolved oxygen is necessary for good water quality and the lack of oxygen in body tissues creates a defect of red blood cells. Drinking water with low dissolved oxygen concentration further exacerbates the condition by constricting blood vessels in the lungs. Dissolved oxygen present in drinking water adds taste and it is a highly fluctuating factor in water. Dissolved Oxygen (DO) is a parameter of aeration and inverse pollution. Well aerated water has reduced pollution than a poorly aerated water body. When the DO is high the pollution is low when the DO is low, the pollution level is high. The borehole water samples have high DO than the tap water samples. The Average DO for public tap water at Molete and Jericho was $0.4 \pm 0.02 \mathrm{mg} / \mathrm{l}$ and $0.5 \pm 0.00 \mathrm{mg} / \mathrm{l}$ respectively while the average DO for borehole at Jericho was 4.85. It is notable that the borehole at Molete shows rather low DO, similar deviation was observed in the BOD of the Molete well water. This could be due toa nearby septic tank or leaky seepage of industrial effluents.

Water treatment or purification can only be effectively carried out when the water quality is known. The results of BOD and DO of water samples from Molete and Jericho areas of Ibadan have shown that borehole water has lower level of pollution than water from the well and public tap as shown in Figure 3 below.

The water from the well at Molete has higher pollution level than the well water at Jericho. However the public tap water in Molete has lower level of pollution than that of Jericho. One can trace the higher pollution level of public tap water in Jericho to discharge of industrial wastes, and sewage into the water. Results of BOD analysis shown in Table 2 and Figure 3 indicates that BOD is high because any value above $3.00 \mathrm{mg} / \mathrm{l}$ is considered high. The borehole water sample is expectedly lower in BOD value than the public tap water and well water because of the depths of the boreholes. However high value of BOD of Borehole water in Molete may be due to poor storage in unclean tank. The public tap water sample from both Molete and Jericho are high because they are drawn from surface (such as stream or rivers) water sources exposed to waste dump and discharge of effluent from the industries which may affect the $\mathrm{pH}$ of the water bodies.

The $\mathrm{pH}$ of a water body is very important because it may affect the solubility and toxicity of metals in the aquatic system, which may have adverse effects on human health. $\mathrm{pH}$ indicates the acidity/alkalinity of the medium. The Ph ranged from $5.88 \pm 0.01$ to $6.88 \pm 0.06$ as shown in the Figure 4 below.

Water with $\mathrm{pH}$ lower than 5 may cause problems due to corrosion because many metals become more soluble in low $\mathrm{pH}$ waters [9]. The results showed that sample W2, W3, and W6 were slightly acidic while sample W1,

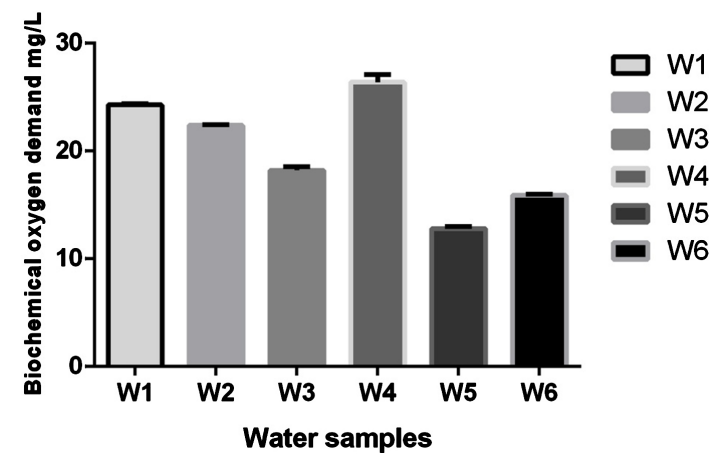

Figure 3. Biochemical oxygen demand of water samples.

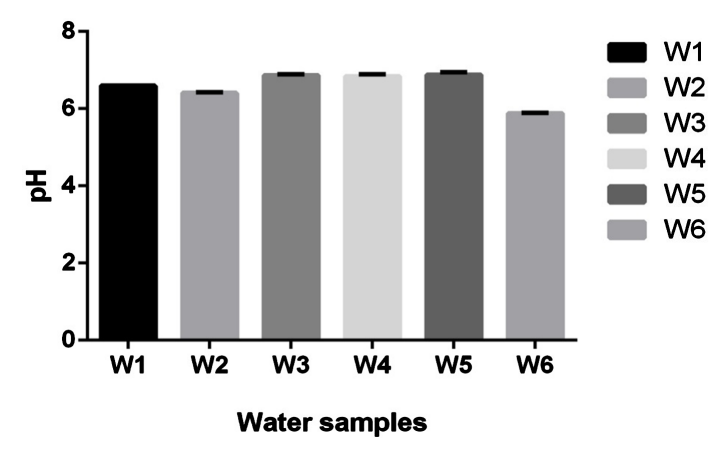

Figure 4. $\mathrm{pH}$ of water samples. 
W4 and W5 were neutral. A pH value of higher than 8.5 indicates that a significant amount of sodium bicarbonate may be present in the water which contributes to the hardness of the water.

Water hardness occurs as a result of the quantity of calcium, magnesium and carbonates present in the water sample. Generally the hardness value of both Molete and Jericho water samples can be classified as soft based on Table 2 and Figure 5.

The water in these areas are good for drinking and laundry based on the hardness values as lather formation with soap is not hindered or prevented.

The coliform count recorded in this study falls within the slightly polluted limits [9] on the pollution of drinking water. Detection of coliform shows the danger of faecal pollution and the consequent hazard of contracting disease through pathogenic (Figure 6).

Organisms disease causing organisms transmitted via drinking water are predominantly of faecal origin, but the coliform count would not constitute much concern without the detection of $E$. coli in the water samples. It has been reported that typical enteropathogenic Escherichia coli is a leading cause of the infantile diarrhoea in developing countries, whereas this is rare in industrialized country [10].

\section{Recommendation}

All the water samples are recommended for both micro-filtration and filtration through activated carbon surface to remove dissolved substances and obnoxious smell originating from decomposition of organic wastes respectively.

\section{Conclusion}

Water from both Molete and Jericho requires some varying degrees of treatment or purification to make it fit for human consumption. High BOD indicates bacteriological activity demanding oxygen for biodegradation of waste or effluents in water. Therefore treatment requirement is targeted toward reduction of bacteriological activity demanding oxygen for biodegradation of waste or effluents in water. The treatment requirement is targeted toward reduction of bacteria (E. coli or Coliform) count.

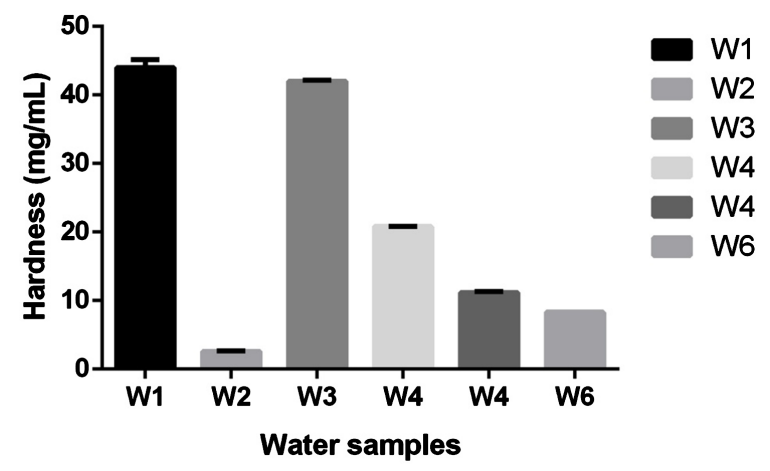

Figure 5. Water Hardness of water samples.

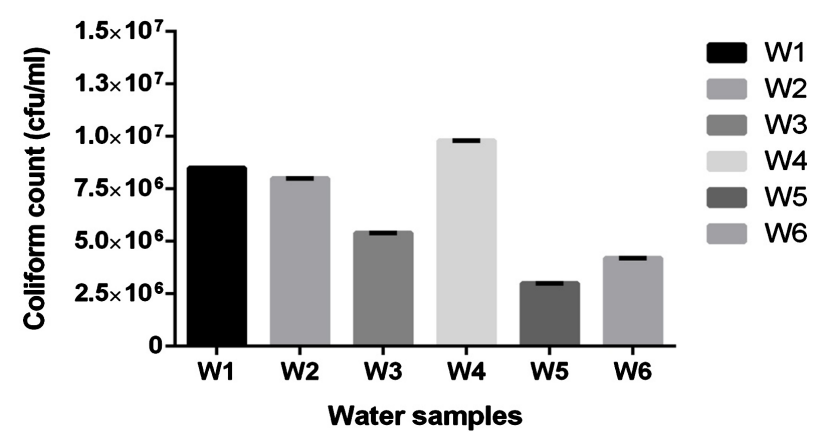

Figure 6. Coliform countof water samples. 
The level of bacterial concentration should be reduced by passing the water through ultra-violet (UV) radiations before consumption and also chlorination.

\section{References}

[1] Tortora, G.J., Funke, R.B. and Case, L.C. (2002) Microbiology: An Introduction. Media update of 7th Edition, Including Bibliography and Index Publisher Daryl Fox, 258-260.

[2] McLellan, S.L., Daniels, A.D. and Salmore, A.K. (2001) Clonal Populatioms of Thermotolerant Enterobacteriaceae in Recreational Water and their Potential Interference with Fecal Escherichia coli Count. Applied and Environmental Microbiology, 67, 4934-4938. http://dx.doi.org/10.1128/AEM.67.10.4934-4938.2001

[3] Ajao, O.G. (1982) Typhoid Perforation: Factors Affecting Mortality and Morbidity. International Surgery, 67, 317319.

[4] Badejo, O.A. and Arigbabu, A.O. (1980) Operative Treatment of Typhoid Perforation and Peritoneal Irrigation: A Comparative Study. Gut, 21, 141-145.

[5] American Public Health Association (APHA) (1999) Standard Methods for the Examination of Water and Wastewater, APHA, Washington DC.

[6] American Public Health Association (APHA) (1998) Standard Methods for the Examination of Water and Wastewater, 20th Edition, APHA, Washington DC.

[7] WHO (2008) Guidelines for drinking-Water Quality [Electronic Resource]: Incorporating 1st and 2nd addenda, Vol.1, Recommendations. 3rd Edition, WHO, Geneva.

[8] UNESCO/WHO/UNEP (1996) Water Quality Assessments—A Guide to Use of Biota, Sediments and Water inEnvironmental Monitoring - Second Edition.

[9] Ajibade, L.T. and Ibrahim, S.I. Assessment of Water Quality and Domestic Uses in Medium-Sized Towns of Niger state, Nigeria (Unpublished).

[10] Trabuisi, L.R., Keller, R. and Tardelli-Gromes, T.A. (2002). Typical and Atypical Enteropathogenic Escherichia coli. Emerging Infectious Diseases, 8, 508-513. http://dx.doi.org/10.3201/eid0805.010385 